\title{
Frost resistance of hazelnut varieties in the Central Black Earth Region of Russia
}

\author{
Natalya Saveleva ${ }^{12 *}$, Alexander Zemisov ${ }^{1}$, Andrey Yushkov $^{12}$, Nadezhda Borzykh ${ }^{1}$, and Vladislav \\ Chivilev $^{1}$ \\ ${ }^{1}$ Federal State Scientific Institution «I. V. Michurin Federal Scientific Center», 30 st. Michurina, \\ Michurinsk, 393770, Russia \\ ${ }^{2}$ Federal State Budgetary Educational Institution of Higher Education "Michurinsk State Agrarian \\ University”, 101 (3), International street, Michurinsk, 393760, Russia
}

\begin{abstract}
The I. V. Michurin Federal Scientific Center has concentrated a hazelnut genotypes collection of various ecological and geographical origin. Based on existing collection contemporary breeding work pointed at creating of new adapted to the soil and climate conditions of the Central Black Earth Region varieties of nuts. In this paper, we analyzed the indicators of frost resistance of hazelnut varieties of the species Corylus avellana L. and Corylus pontica C. (Koch.). Based on a comparative assessment valuable genotypes identification for producing and further breeding was the main purpose of the study. The paper shows the results of studying of 37 hazelnut varieties by the reaction to temperature decrease up to $-40^{\circ} \mathrm{C}$ after standard quenching. We have identified the sources of high frost resistance, among which a special place is occupied by a new Schelkunchik variety. This genotype has no damage of the bark and cambium tissues, reversible damage of wood and vegetative buds, and a low level of male inflorescences lethality $(2 \%)$. We have identified the frost resistance potential of the varieties Moskovskiy rubin, Ivanteevskiy krasniy, Pushkinskiy krasniy, Moscovskiy ranniy, Academik Yablokov. It is sufficient for cultivation of those varieties at the conditions of the Central Black Earth Region of Russia.
\end{abstract}

\section{Introduction}

Hazel, as the ancestor of modern hazelnuts (Corylus avellana L. and Corylus pontica C. (Koch.), is one of the most ancient garden crops. Since the 16th century, the selection of large-fruited forms of hazel in some countries of Europe and the USA has been carried out. All nut production was based on the cultivation of those forms. Since the second half of the 20th century, breeding programs have been adopted in Italy, Spain, France, and by the end of the last century in Turkey. The creation of new varieties for industrial production began at a rapid pace $[1,2,3]$.

Modern domestic and foreign breeding programs are aimed at increasing the yield, the weight of the nut kernel, improving the taste qualities, as well as increasing resistance to

\footnotetext{
*Corresponding author: saveleva natalya nic@mail.ru
} 
negative environmental factors [4-7]. Research of the DNA structure is currently at the forefront of science now. It helps to accelerate the selection process [8-12].

Hazelnut plants are quite winter hardy. However, because the main production is concentrated in the warm climate countries, winter hardiness researches is poorly covered in literary sources $[13,14]$.

Walnuts production is occupied about $50 \%$ of all nut-bearing crops in the world. The second place belongs to the almonds production. The third place is occupied by hazelnuts, the leading producer of which is Turkey, providing $70 \%$ of the world harvest. There is a tendency to increase the consumption of nuts in the world. The spread of the healthy eating trend has led to an increase in the consumption of hazelnuts. Exporting countries grow several standardized varieties such as Barcelona, Tonda di Giffoni, TGL, Tonda Romana, Negret and Tombul. They provide homogeneous high-quality products that meet the requirements of the global confectionery industry first. Fitness industry, pharmacology and cosmetology are also increasing demand. In addition, Corylus L. plants are promising objects for decorative gardening and protective afforestation $[15,16]$.

Currently, hazelnuts are mainly imported to our country. According to HuzelIndustry, it is more than $95 \%$ of foreign products in the total volume of nuts. The soil and climatic conditions of the Central Black Earth Region are suitable for environmentally sustainable hazelnuts varieties growing. To create them, academician N.Savelev created a collection of 60 varieties and forms of hazelnut of various ecological and geographical origin and an extensive hybrid fund at the Institute of Genetics and Breeding of Fruit Plants.

Recently, under of "climate nervousness" conditions genotypes can be unstable to adverse environmental factors [17]. In this regard, the study of plant reaction to a critical air temperature decrease up to $-40^{\circ} \mathrm{C}$ becomes particularly relevant.

The selection of high frost resistance hazelnut varieties in the conditions of the Central Black Earth Region of Russia based on the results of the assessment of resistance to temperature decrease up to $-40{ }^{\circ} \mathrm{C}$ was the main goal of the work.

\section{Materials and methods}

Our study was conducted at Federal State Scientific Institution «I. V. Michurin Federal Scientific Center» in 2017-2020. 37 hazelnuts varieties from the Institute of Genetics and Breeding of Fruit Plants collection were selected for research. Tambovskiy ranniy variety was used as a control. The study of frost resistance was carried out by direct freezing of annual shoots at a temperature of $-40{ }^{\circ} \mathrm{C}$ after preliminary standard quenching for 10 days at a temperature of -5 and $-10{ }^{\circ} \mathrm{C}$. The indicators of low temperature damage to the tissues of the bark, cambium and wood, vegetative buds and male inflorescences were analyzed. The freezers HC-280/75, TC-180 Jeio Tech were used in the work. Statistical processing of the obtained indicators was carried out using packages of applied computer programs (Microsoft Office Excel 2010, STATISTIKA 6.0 for Windows).

\section{Results and discussion}

There was a significant difference between max and min air temperature in 2017-2020 during the growing season. In On average in April, the difference was $27.7^{\circ} \mathrm{C}$, but the minimum temperature was $-2.3^{\circ} \mathrm{C}$, which did not cause to the generative organs damage. In the winter months, the temperature did not fall below $-26.8^{\circ} \mathrm{C}$, all genotypes successfully endured the cold, but some varieties of southern selection (Rimskiy, Barselona) had male inflorescences freezing. On average, $406.5 \mathrm{~mm}$ of precipitation fell in three years, which is $23.7 \%$ less than the annual average. In this case, it is necessary to provide for watering in hazelnut plantations. 
Our research shows that the bark and cambium tissues were characterized by less damage. However, Garibaldi and Dedoplis titi varieties had freezing level higher than 2.0 points (Table 1).

Table 1. Annual branches, buds and catkins tissues of hazelnut varieties freezing level after $-40^{\circ} \mathrm{C}$ freezing

\begin{tabular}{|c|c|c|c|c|c|c|}
\hline \multirow[t]{2}{*}{ Variety } & \multicolumn{4}{|c|}{ Tissue (point) } & \multirow{2}{*}{$\begin{array}{l}\text { Buds } \\
\text { (point) }\end{array}$} & \multirow{2}{*}{$\begin{array}{c}\text { Catkins } \\
\text { lethality, } \\
(\%)\end{array}$} \\
\hline & Bark & Cambium & Wood & Average & & \\
\hline Pervenets & 0.1 & 0.1 & 1.9 & 1.2 & 1.9 & 98 \\
\hline Barselona & 1.4 & 1.5 & 2.7 & 2.6 & 4.0 & 100 \\
\hline Sikler & 0.7 & 0.8 & 2.1 & 1.7 & 3.0 & 100 \\
\hline Nottingemskiy & 1.6 & 1.7 & 2.9 & 2.4 & 4.2 & 100 \\
\hline Luiza & 0.8 & 0.9 & 2.4 & 1.9 & 4.0 & 100 \\
\hline Kadetten & 0.8 & 0.8 & 2.2 & 1.7 & 4.1 & 100 \\
\hline Rimskiy & 1.0 & 1.0 & 1.6 & 1.9 & 4.0 & 100 \\
\hline Garibaldi & 2.0 & 2.0 & 3.2 & 2.8 & 4.2 & 100 \\
\hline Barra & 1.3 & 1.3 & 2.4 & 2.2 & 3.8 & 100 \\
\hline Cherkesskiy-2 & 1.2 & 1.2 & 2.7 & 2.2 & 3.8 & 100 \\
\hline $\begin{array}{l}\text { Barselonskiy } \\
\text { uglovatiy }\end{array}$ & 1.2 & 1.3 & 2.5 & 2.0 & 4.0 & 100 \\
\hline Ata-baba & 0.7 & 0.7 & 2.4 & 1.8 & 3.7 & 100 \\
\hline $\begin{array}{l}\text { Kerasund } \\
\text { krugliy }\end{array}$ & 1.4 & 1.4 & 2.9 & 2.4 & 4.8 & 93 \\
\hline Tzheniz dzu-dzu & 1.6 & 1.7 & 3.3 & 2.6 & 4.4 & 100 \\
\hline Severniy-42 & 0 & 0 & 1.3 & 1.1 & 1.5 & 100 \\
\hline Kosford & 1.5 & 1.5 & 2.0 & 2.0 & 4.1 & 100 \\
\hline $\begin{array}{l}\text { Akademik } \\
\text { Yablokov }\end{array}$ & 0.2 & 0.3 & 1.6 & 1.0 & 1.8 & 50 \\
\hline Kudryavchik & 1.3 & 1.3 & 2.4 & 2.0 & 3.8 & 100 \\
\hline Gustav & 1.7 & 1.7 & 3.2 & 2.7 & 4.0 & 100 \\
\hline $\begin{array}{l}\text { Lombardskiy } \\
\text { beliy }\end{array}$ & 1.8 & 1.8 & 2.9 & 2.2 & 4.0 & 100 \\
\hline Buttner & 1.3 & 1.3 & 2.7 & 2.2 & 4.1 & 100 \\
\hline Dedoplis titi & 2.8 & 2.8 & 3.4 & 3.3 & 4.8 & 100 \\
\hline Kuntzemullers & 0.4 & 0.4 & 2.2 & 1.6 & 2.8 & 100 \\
\hline Royal & 1.7 & 1.7 & 2.5 & 2.3 & 4.3 & 100 \\
\hline $\begin{array}{l}\text { Lombardskiy } \\
\text { krasniy }\end{array}$ & 1.5 & 1.5 & 3.3 & 2.5 & 3.9 & 100 \\
\hline Cherkesskiy-1 & 1.0 & 1.0 & 2.5 & 2.1 & 4.0 & 100 \\
\hline President & 1.0 & 1.1 & 2.2 & 1.9 & 3.4 & 100 \\
\hline Nemsa & 1.7 & 1.9 & 3.3 & 2.7 & 3.7 & 100 \\
\hline Kuktashen & 1.7 & 1.8 & 3.2 & 2.7 & 4.3 & 100 \\
\hline $\begin{array}{l}\text { Chudo } \\
\text { Bolvillera }\end{array}$ & 1.3 & 1.3 & 2.3 & 2.2 & 4.2 & 100 \\
\hline $\begin{array}{l}\text { Moskovskiy } \\
\text { rubin }\end{array}$ & 0.1 & 0.1 & 1.1 & 0.9 & 1.5 & 2 \\
\hline $\begin{array}{l}\text { Ivanteevskiy } \\
\text { krasniy }\end{array}$ & 0.3 & 0.3 & 1.7 & 1.0 & 2.0 & 76 \\
\hline
\end{tabular}




\begin{tabular}{|l|c|c|c|c|c|c|}
\hline $\begin{array}{l}\text { Tambovskiy } \\
\text { ranniy (c) }\end{array}$ & 0.1 & 0.2 & 1.2 & 1.1 & 1.7 & 60 \\
\hline $\begin{array}{l}\text { Pushkinskiy } \\
\text { krasniy }\end{array}$ & 0.1 & 0.2 & 1.3 & 1.0 & 1.6 & 27 \\
\hline $\begin{array}{l}\text { Moskovskiy } \\
\text { ranniy }\end{array}$ & 0 & 0.1 & 0.8 & 0.7 & 1.6 & 60 \\
\hline Kavkaz & 1.7 & 2.1 & 3.2 & 2.8 & 3.5 & 100 \\
\hline Schelkunchik & 0 & 0 & 1.1 & 0.5 & 1.3 & 2 \\
\hline SSD05 & & & & 0.21 & 0.19 & \\
\hline
\end{tabular}

The Moskovskiy ranniy, Ivanteevskiy krasniy, Pushkinskiy krasniy, Academik Yablokov, Pervenets varieties had a damage level from 0-0.1 to 0.3 points, which corresponds to or below of the control. The observed wood freezing of these varieties did not exceed 1.9 points. Those varieties are highly resistant to low temperature. The tissue damage average level are in the range from 0.7 (Moscovskiy ranniy variety) to 1.2 (Pervenets variety) points. The vegetative buds freezing of the noted varieties did not exceed 2.0 points. Pushkinskiy krasniy and Moscovskiy ranniy varieties has the lowest level (1.6 points). Such damage is quite reversible and does not cause significant injury to the growth and development of plants. The observed male inflorescences lethality of the majority of studied varieties was $100 \%$. However, at Pushkinskiy krasniy (27\%), Moscovskiy ranniy (60\%), Ivanteevskiy krasniy (76\%), Academik Yablokov (50\%) varieties it remained at the Tambovskiy ranniy control variety $(60 \%)$ level.

The Schelkunchik, Moscovskiy rubin and Severniy 42 varieties were characterized by the greatest frost resistance. The Schelkunchik variety was created at the Institute of Genetics and Breeding of Fruit Plants named after I. V. Michurin. It is characterized by high productivity and environmental sustainability. In the noted varieties, there was practically no damage to the bark and cambium tissues, the freezing level of wood was 1.1 points (Schelkunchik, Moscovskiy rubin) and 1.3 points (Severniy 42). Vegetative kidneys suffered by 1.3 and 1.5 points, respectively. Only $2 \%$ of male inflorescences died in the adapted Schelkunchik and Moscovskiy rubin varieties.

\section{Conclusion}

The stability potential of Schelkunchik, Moscovskiy rubin, Ivanteevskiy krasniy, Pushkinskiy krasniy, Moscovskiy ranniy, Academik Yablokov varieties is sufficient for cultivation in the conditions of central Russia. We recommend it for production plantings and used in further breeding. A promising direction for further work is also the implementation of studies on the identification of genetic determinants (genes, quantitative loci - QTL) of resistant forms frost tolerance. It is particularly worth highlighting the Schelkunchik and Moscovskiy rubin varieties, which we recommend as one of the parent forms when creating mapping populations for analyzing the inheritance of this trait and identifying DNA markers linked to frost resistance genetic determinants.

\section{References}

1. S.G. Biganova, Yu.I. Sukhorukikh, E.K. Pchikhachev, New Tech., 2, 135-143 (2020) https://doi.org/10.24411/2072-0920-2020-10214

2. A. İslam, Ak. Ziraat Dergisi, 7(2), 259-266 (2018) https://doi.org/10.29278/azd.476665

3. I.S. Kosenko, A.I. Opalko, O.A. Balabak, O.A. Opalko, A.V. Balabak, Plant var. stud. protect., 13(3), 245-251 (2017) https://doi.org/10.21498/2518-1017.13.3.2017.110706 
4. S.A. Mehlenbacher, Acta Hortic, 1226, 73-78

(2018) https://doi.org/10.17660/ActaHortic.2018.1226.10

5. T.J. Molnar, J.J. Lombardoni, M.F. Muehlbauer, J.A. Honig, S.A. Mehlenbacher, J.M. Capik, Acta Hortic, 1226, $79-86$ (2018) https://doi.org/10.17660/ActaHortic.2018.1226.11

6. V.R. Sathuvalli, S.A. Mehlenbacher, B.C. Peterschmidt, D.C. Smith, Acta Hortic, 1052, 23-25 (2014) https://doi.org/10.17660/ActaHortic.2014.1052.2

7. M. Xie, J.L. Zheng, D.M. Wang, Acta Hortic, 1052, 41-43 (2014) https://doi.org/10.17660/ActaHortic.2014.1052.4

8. L. Leinemann, W. Steiner, B. Hosius, O. Kuchma, W. Arenhövel, B. Fussi, B. Haase, R. Kätzel, M. Rogge, R. Finkeldey, Plant Syst. Evol., 299, 369-378 (2013) http://dx.doi.org/10.1007/s00606-012-0727-0

9. V.R. Sathuvalli, H.L. Chen, S.A. Mehlenbacher, D.C. Smith, Genomes, 7(2), 337-345 (2011) https://doi.org/10.1007/s11295-010-0335-5

10. E.R. Rowley, D.W. Bryant, S.E. Fox, S.A. Givan, S.A. Mehlenbacher, T.C. Mockler, Acta Hortic., 1052,75-78 (2014) https://doi.org/10.17660/ActaHortic.2014.1052.8

11. C. Beltramo, P. Boccacci, M.A. Sandoval Prando, R. Botta, E. Portis, Acta Hortic., 1052, 99-104 (2014) https://doi.org/10.17660/ActaHortic.2014.1052.12

12. S. Franco, B. Pancino, V. Cristofori, Acta Hortic., 1052, 347-352 (2014) https://doi.org/10.17660/ActaHortic.2014.1052.48

13. J. Wanjiku, H. Bohne, Eur. J. Hortic. Sci., 81(1), 3-12 (2016) http://dx.doi.org/10.17660/eJHS.2016/81.1.1

14. I.S. Kosenko, A.F. Balabak, S. Sonko, O.A. Balabak, Ukr. Journ. of Eco., 9(3), 117-125 (2019)

15. B. Baldwin, Y. Guisard, Acta Hortic., 1052, 321-327 (2014) https://doi.org/10.17660/ActaHortic.2014.1052.45

16. G.L. Malvicini, A. Roversi, Acta Hortic., 1052, 215-220 (2014) https://doi.org/10.17660/ActaHortic.2014.1052.28

17. J. Kreyling, C. Beier, BioSci., 63(9), 763-767 (2013) https://doi.org/10.1525/bio.2013.63.9.12 